\title{
The Christian Right, the Federal Courts, and the CONSTITUTION IN THE UNITEd STATES
}

\author{
Judith A. Garber*
}

\section{INTRODUCTION}

There's more than one way to skin a cat, and there's more than one way to take a black robe off the bench. - Tony Perkins, President, Family Research Council ${ }^{1}$

We set up the courts. We can unset the courts. We have the power of the purse. - Representative Tom DeLay, thenMajority Leader, United States House of Representatives ${ }^{2}$

Twenty-five years have passed since the newly formed Moral Majority helped put Ronald Reagan in the White House and a Republican majority in the United States Senate. The Moral Majority was one organization (and its founder, the Reverend Jerry Falwell, one figure) at the centre of an emerging evangelical Protestant social movement. This movement was galvanized by two aims: defeating the Equal Rights Amendment, ${ }^{3}$ which Congress submitted to the states for consideration in 1972, and contesting the U.S. Supreme Court's 1973 Roe v. Wade 4 ruling, which recognized a constitutional right to abortion. In the early 1980s, "New Christian Right" was an accurate description of the first widespread public engagement of evangelicals in half a century.

The author thanks Janna Promislow and Naomi Schmold for their helpful comments on earlier drafts of this article. Quoted in Peter Wallsten, "2 Evangelicals Want to Strip Courts' Funds" Los Angeles Times (22 April 2005).

Quoted in ibid.

H.R. J. Res. 208 (92nd Congress, $2^{\text {nd }}$ sess.). The proposed constitutional amendment read: "Equality of rights shall not be denied or abridged by the United States or by any State on account of sex."

4410 U.S. 113 (1973), online, LII <http://supct.law.cornell.edu/ supct/html/historics/USSC_CR_0410_0113_ZS.html>.
The current Christian Right ${ }^{5}$ is built upon its 1970s precursor, but it has moved well beyond it to become a more radical movement in both style and substance. A centrepiece of this radicalism is a concerted, unabashed effort to make American courts - most obviously, but certainly not exclusively, the federal appellate courts - into conservative Christian adjuncts to the electoral, legislative, and administrative processes. Three elements comprise this effort: 1) attacks on judicial independence and authority carried out by means of electoral, legislative, and cultural

John C. Green argues:
Although no name is perfect, "Christian right" is preferable to the more common term, "religious right," which properly refers to a possible alliance of traditionalists from all religious groups, including evangelicals, conservative mainline Protestants, traditionalist Catholics, Orthodox Jews, and so forth. .. Although there is evidence for this broader "religious right," most of the action has been and is with the narrower Christian right. A wide range of conservative denominations are visible as opponents of same-sex marriage, but Green's observation remains useful.

The Christian Right at the Millennium (Washington: The American Jewish Committee, April 2001), online: $<$ http://www.ajc.org/InTheMedia/PublicationsPrint. asp?did=139> [Green $]$

What evangelical Protestants themselves wish to be called is an issue of some controversy. According to Green, "the term 'Christian right' has, indeed, been shed by the group it's meant to describe. Why? Partly because liberals . . . have finally managed to attach extremist associations to the phrase... The new favored term is 'the pro-family movement...." Quoted in Timothy Noah, "Red-State PC: Why You Can't Call Them 'the Christian Right", Slate (8 November 2004), online: $<$ http://slate.com/toolbar.aspx?action=print\&id=2109370 $>$. The term "Christianist," an evident, critical reappropriation of "Islamist," which has been frequently used in the West since September 11, 2001, to refer to Islamic theocrats, had been circulating on the Internet; it was placed into the mainstream by Hendrik Hertzberg in a commentary on Congressional efforts to displace judicial authority in the Terri Schiavo case. See "Matters of Life" The New Yorker (4 April 2005) at 33-34. 
politics; 2) an expectation of control over who is appointed to the Supreme Court and lower federal courts; and 3) a reliance on constitutional litigation as a primary method of social change.

As I will discuss, elections are the bedrock of the Christian Right's effort to shape the judiciary, and governance generally, in its image; nevertheless, the combination of majoritarian and countermajoritarian tactics also marks the Christian Right approach to the courts as genuinely radical. Thus, the remarks by Tony Perkins and Tom DeLay at the beginning of this article, which followed Terri Schiavo's deeply politicized death in Florida in March 2005, and which typify one form of attack on the courts, are part of what is actually a complicated approach to the courts. They must be examined alongside Christian Right organizations' intense interest in the two Supreme Court seats that became vacant in the summer of 2005 and an ongoing legal mobilization strategy that is as serious and creative as the movement's interventions in democratic politics.

\section{ThE TIES THAT Bind "ChRISTIAN" AND "RIGHT"}

One of my goals in life is to give the Republican Party courage. - Dr. Rick Scarborough, President, Vision America ${ }^{6}$

I don't know of a single business group involved in the judicial nominees. Nada, none, zip. - R. Bruce Josten, Executive Vice President, U.S. Chamber of Commerce ${ }^{7}$

Quoted in Shailagh Murray, "Filibuster Fray Lifts Profile of Minister: Scarborough Has Network and Allies" Washington Post (8 May 2005) A 01, online: <http://www.washingtonpost. com/wp-dyn/content/article/2005/05/07/AR02005050701266. html $>$. Only six months after the 2004 election, Scarborough claimed already to have recruited several thousand members to his multidenominational "Patriot Pastors" political network, with the aim of influencing the 2006 elections. Information about Scarborough's (interlinked) organizations can also be found on the websites of Vision America $<$ http://www.vision.america.us $>$ and the Judeo-Christian Council for Constitutional Restoration <http://www. stopactivistjudges.org $>$.

Quoted in Jonathan Weisman \& Jeffrey H. Birnbaum, "Business Groups Tire of GOP Focus on Social Issues" Washington Post (24 May 2005) A01, online: <http://www. washingtonpost.com/wp-dyn/content/article/2005/05/23/
Evangelical Protestants retreated into a "defensive separatism" in the 1920 s, following the loss of major cultural and political battles over the teaching of evolution and Prohibition. ${ }^{8}$ Upon its return to public engagement, Christian conservatism very quickly re-established itself as a prominent feature of the American political landscape, as prominent as the progressive (Black, feminist, anti-war, etc.) social movements that became powerful in the electoral and legislative arenas in the 1960s. Today, groups such as Focus on the Family, the Christian Coalition of America, and Concerned Women for America are becoming as recognizable as political advocates as the venerable American Civil Liberties Union (ACLU), National Association for the Advancement of Colored People (NAACP), and Planned Parenthood Federation of America. In short, it is taken for granted that evangelical Protestants in the U.S. are politically attentive and mobilized, and that the Republican Party cultivates access to their support, resources, savvy, and daring.

During the presidency of George W. Bush, however, and most clearly since his re-election in 2004 along with a larger Republican majority in Congress, the alliance between conservative politics and conservative Christianity has once again become new. The movement that I refer to as the Christian Right has never remained static. It has survived scandals within flagship organizations (one of which led to the demise of the Moral Majority in 1989), learned from embarrassing defeats (most notably, the persistent popularity of Bill Clinton despite his sexual improprieties and impeachment), welcomed the support of Catholic Church on a number of highprofile issues (such as embryonic stem cell research), and proliferated its institutional bases both inside and outside of democratic processes.

Ultimately, the goal of the Christian Right is a seamless integration of religious, political, and

AR2005052301938.html>.

8 Dennis R. Hoover \& Kevin R. den Dulk, "Christian Conservatives Go to Court: Religion and Legal Mobilization in the United States and Canada" (2004) 25:1 International Political Science Review 9 at 24. Also see Clyde Wilcox, Onward Christian Soldiers? The Religious Right in American Politics (Boulder, CO: Westview Press, 1996) at 30-34 [Wilcox]; and Green, supra note 5. 
legal institutions achieved through elected officials, appointed officials, and actors in civil society who share a religiously conservative worldview. The movement's anchor issues are opposition to reproductive rights, the right to die, and gay and lesbian rights, and support for manifold forms public religious expression. However, the concerns of Christian Right groups implicate the universe of American constitutional law. Constitutional provisions on the conservative Christian agenda include: all of the First Amendment expressive and religious liberties; the Second Amendment "right to bear arms"; personal privacy rights grounded in the Fourth Amendment; criminal process rights contained in the Fifth, Sixth, and Eighth Amendments, especially concerning death penalty cases; the Fifth Amendment provision regarding the "taking" of private property; the architecture of federalism embedded in the Tenth and Eleventh Amendments; and the Fourteenth Amendment Equal Protection Clause. What is the constitutional promised land for social conservatives is thus a state of siege for libertarians and progressives, who warn that attacks on judicial independence, courts' jurisdiction, and the rule of law itself are the underpinnings of an American theocracy. ${ }^{9}$

The institutional relationships between "Christian" and "Right" are complex and strong. Some critics of American politics would point to elite connections. For example, the National Policy Council, a secretive organization started in 1981 "as an umbrella organization of right-wing leaders who would gather regularly to plot strategy, share ideas and fund causes and candidates," has as members and supporters ultraconservative luminaries in the religious, political, military, business, and media worlds. ${ }^{10}$ To appreciate the radicalism of the stance towards courts and the law within the Christian Right, however, one must look beyond groups with only hundreds of (albeit powerful) members. The belief

Didi Herman, "The Gay Agenda is the Devil's Agenda: The Christian Right's Vision and the Role of the State" Craig A. Rimmerman, Kenneth D. Wald, \& Clyde Wilcox, eds., The Politics of Gay Rights (Chicago: University of Chicago Press, 2000) 139. Also see the Theocracy Watch website, online: $<$ http://www.theocracywatch.org $>$

10 Jeremy Leaming \& Rob Boston, "Behind Closed Doors" Church \& State (October 2004), online: American United for the Separation of Church and State $<$ http://www.au.org/site/ News2 ? page $=$ NewsArticle $\&$ id $=6949 \&$ abbr $=c s \_>$. that the judiciary should and can be made to reflect a certain set of values has its origins in the elections of the past quarter-century. More specifically, it has grown out of the brilliant electoral strategies honed by a complex of Republican politicians, Republican party organizations (at the national, state, and county levels), Christian organizations, and popular church leaders. Among the most important figures in the implementation and spread of these strategies have been the professional consultants who bring the same types of communications and constituency-building skills to church pastors with national aspirations as to political candidates. ${ }^{11}$ The movement has excelled at candidate recruitment and training, whether for partisan or nonpartisan offices, and including positions in all branches and all levels of government. Informally, it has made activists out of political amateurs who become energized by the types of concerns articulated within the conservative Christian milieu.

Early on, evangelicals entered politics mostly through local school board elections, and their successes in that arena, though inconsistent, have been publicized widely in the media and mobilized against intensely by liberal and moderate opponents. ${ }^{12}$ But Americans fill more than 513,000 public offices through elections. It is significant that religious conservatives have organized to contest the spectrum of the 494,000 local elected offices ${ }^{13}$ given the impact of those positions on day-to-day governance.

11 See, for example, Jonathan Mahler, "The Soul of the New Exurb" New York Times Magazine (27 March 2005) 30.

12 Control of school boards by candidates affiliated with the Christian Right is not only a small-town or Bible Belt phenomenon, as one might suppose. In 1993, angered by the introduction of a multicultural curriculum, the Christian Coalition and other groups succeeded in removing the head of the New York City public school system and won elections for control of a large number of the city's school districts. Wilcox, supra note 8 at 82 . The shifting balance of control on the Kansas State Board of Education since 1999, fought largely over the teaching of evolution, has received national and international attention. Also see Melissa M. Deckman, School Board Battles: The Christian Right in Local Politics (W ashington: Georgetown University Press, 2004).

13 U.S. Department of Commerce, Bureau of the Census, 1992 Census of Governments: Popularly Elected Officials (Washington: U.S. Government Printing Office, June 1995) at 1, online: <http://www.census.gov/prod/2/gov/gc/gc92 12 . $\mathrm{pdf}>$. 
It is even more crucial that these activists have not limited their electoral ambitions to school boards, county commissions, or small-town mayorships. The grassroots organizing that is required to win lower-profile elections - and to control Republican Party organizations - has proven to be a solid foundation for higher-level campaigns. This advantage was evident when Republicans won control of both houses of Congress in 1994 and became impossible to ignore with the 2000 Presidential election. ${ }^{14}$ Candidates who vaunt their conservative Christian values and associations have increasingly won governorships and other powerful statewide positions such as attorney general, secretary of education, and secretary of state (the latter, frequently the official who controls election administration). So many seats in the U.S. House of Representatives and the Senate are occupied by religious conservatives that, based on their votes in 2003, fully thirty-nine of the fifty-one Senate Republicans (plus one Democrat) earned scores of more than 95 percent from three major Christian Right organizations; 136 of 229 House Republicans received scores of at least 90 percent. ${ }^{15}$ Electoral activity over time, then, has seen the actions and discourses of Republican politicians converging with the agendas of religious denominations and organizations in various areas of public policy - social and cultural policy most obviously, but also science, economic, national security, and foreign policy.

The movement towards shared policy goals between church (or temple, mosque, or synagogue) and state demands examination, in

14 Prior to the 2000 election, some in the Christian Right were in a "'post-impeachment funk,", in the words of a movement founder, Paul Weyrich. Some on the left believed the entrance of the Christian Right into the Republican nomination battle might split the party. Harry Jaffe, "Backward, Christian Soldiers" Salon (10 April 1999), online: Salon.com <http:// www.salon.com/news/feature/1999/04/09/christianright $>$. That both sides underestimated the resilience and influence of religious conservatives is due in part to the transformation of the "compassionate conservative" candidate George W. Bush into President Bush, who, rendered more powerful overall by the "war on terrorism," has governed with deference to the power of the Christian Right electorally as well as in Congress.

15 Scores are the average of scorecards issued by the Family Research Council, Eagle Forum, and Christian Coalition. Glenn Scherer, "The Godly Must Be Crazy: Christian-Right Views are Swaying Politicians and Threatening the Environment" Grist Magazine (27 October 2005), online: $</ 2004 / 10 / 27 /$ scherer-christian>. part because it is occurring in a national context where government's ability to take the side of - to "endorse" - religion is constitutionally quite narrow. ${ }^{16}$ With the First Amendment's Establishment Clause less open to interpretation, the Rehnquist Court expressed its sympathies with religious expression by expanding the scope of the Exercise Clause and Free Speech Clause. ${ }^{17}$ This shift owes much to intensive legal activity by certain Christian Right organizations, as I discuss below.

But the radicalism of the current situation also lies in the normalization of public officials mixing their faith with their jobs, in practice. Thus, it may remain contentious and newsworthy but it is no longer surprising that Texas Governor Rick Perry went to a Fort Worth Christian school to sign a law restricting abortions for minors ${ }^{18}$ or that an Ohio county sheriff's "official letterhead ... reads, "With God, all things are possible.",19 Neither does it seem particularly strange that the Majority Leader of the U.S. Senate, Bill Frist, used the "Justice Sunday" event sponsored by Focus on the Family and the Family Research Council at a Baptist "megachurch" in Louisville, Kentucky, to rally support for appellate court nominees that Senate Democrats had been blocking as extremist. Frist's taped message was

16 The "endorsement" test for determining whether a particular religious expression or display "makes religion relevant, in reality or public perception, to status in the political community" was first offered by Justice Sandra Day O'Connor in concurrence in Lynch v. Donnelly, (1984) 465 U.S. at 692 , online: <http://supct.law.cornell.edu/supct/html/historics/ USSC_CR_0465_0668_ZS.html> (permitting the display of a crèche by the city). It has been determinative in many Establishment Clause cases, including most recently $M c$ Creary County v. American Civil Liberties Union of Kentucky, (2005) 545 U.S. [03-1693], online: LII <http://straylight.law. cornell.edu/supct/html/03-1693.ZS.html> (forbidding the display of the Ten Commandments in two county courthouses), though not Van Orden v. Perry, (2005) 545 U.S. ___ [No. 031500], online: LII $<\mathrm{http}$ ://straylight.law.cornell.edu/supct/html/ 03-1500.ZS.html $>$ (permitting a monument inscribed with the Ten Commandments on the Texas capitol grounds). With Justice O'Connor's replacement on the Court by Samuel Alito, this test may well become defunct.

17 The First Amendment begins: "Congress shall make no law respecting an establishment of religion, or prohibiting the free exercise thereof; or abridging the freedom of speech...."

18 The bill-signing was orchestrated via "an e-mail message sent to religious groups" and was initially intended to be filmed for use in Perry's 2006 reelection campaign. Ralph Blumenthal, "Texas Governor Draws Criticism for a Bill-Signing Event at an Evangelical School" New York Times (6 June 2005) A 12.

19 James Dao, "Movement in the Pews Tries to Jolt Ohio" New York Times (27 March 2005) 14. 
reportedly "broadcast to several hundred churches by satellite, thousands of people over the Internet and 61 million households over Christian radio and television stations" (while in the same city, "[a]bout 1,200 liberal Christians gathered at a rally at a Presbyterian church . . . to protest what one speaker, the left-leaning evangelical Jim Wallis, called 'a declaration of religious war' and 'an attempt to hijack religion"'). ${ }^{20}$ Conservative institutions now share messengers and messages as a matter of course, as they share the media that publicize these actors and ideas.

\section{THE 2004 ELECTIONS}

They just make more Republicans. Jennifer Palmieri, Communications Director, Kerry-Edwards Ohio ${ }^{21}$

[W] e're the ones who can gear up people around the country. The engine has been idling since the election, and all we have to do is rev it up again. - Tony Perkins, President, Family Research Council ${ }^{22}$

The 2004 elections revealed the connections between popular, representative politics influencing nominations, campaigning, and lobbying - and the potential force of the Christian Right in shaping the judiciary. In the presidential election, Ohio and the several other competitive "swing" states served as laboratories for twentyfirst-century versions of electioneering that were pioneered by conservative Christian and Republican campaign consultants in the crucial 1970s-1980s period. Throughout the Bush-Kerry contest, Republicans exploited their "sleek and flexible arsenal of the most effective weapons in contemporary politics: high-impact TV ads, precision polling, laser-guided direct mail." ${ }^{, 23}$ They created "a stunning turnout" by identifying

20 David D. Kirkpatrick, "Frist Seeks Christian Support to Stop Filibusters" New York Times (25 April 2005) A 14.

21 Quoted in Matt Bai, "Who Lost Ohio?" New York Times Magazine (21 November 21) 66 at 74 [Bai, "Ohio"].

22 Quoted in Alan Cooperman, "Evangelical Groups Plan Aggressive Drive for Nominee: Campaign Seeks Solid Conservative" Washington Post (4 July 2005) A06, online: $<$ http://www.washingtonpost.com/wp-dyn/content/article/ 2005/07/03/AR2005070300908. html>.

23 Matt Bai, "The Multilevel Marketing of the President" New York Times Magazine (25 April 25) 42 at 46 [Bai, "Multilevel Marketing"]. unmobilized "white, conservative and religious voters" through "a volunteer network using local party organizations, union rolls, gun clubs and churches." ${ }^{24}$ A figure generated by conservatives (and cited by progressives) is the 4 million "Christian fundamentalists, evangelicals or Pentecostals [who] did not vote in 2000," a group Republicans targeted in completing the construction of their electoral base in $2004 .^{25}$ It is no coincidence that Republicans located so many new voters in the new "exurbs" of metropolitan areas, or precisely where evangelical, often theologically untraditional megachurches are sprouting. Megachurch ministers, many of whom came of age during the heyday of the New Christian Right, helped recruit voters who, according to the Bush-Cheney campaign's liaison to social conservatives "said they were motivated first and foremost by their values.",26 The longstanding practice, begun by the Moral Majority, of the mass distribution of voter guides in churches prior to elections - according to the mainstream media, the Christian Coalition alone distributed 30 million guides in $2004^{27}$ - now seems a necessary but insufficient mode of electoral influence.

These electoral strategies have manifold implications for the American judiciary. First, and most straightforwardly, by squeezing votes out of the Electoral College, Christian conservatives

\footnotetext{
See Bai, "Ohio," supra note 21 at 74

25 John Nichols, "Karl Rove's Legal Tricks," The Nation (22 July 2002), online: <http://www.thenation.com/doc.mhtml?i= 20020722\&s=nichols $>$. And see Candi Cushman, "Remember Florida" Citizen, online: Family.org <http://www.family.org/ cforum/citizenman/coverstory/a0032633.cfm>

26 Gary Marx, quoted in Mahler, supra note 11 at 37 . Bai also notes the benefits for Republicans in creating, in deindustrialized states, "a political machine for the new economy" out of the "fast-growing, conservative communities . rising almost monthly out of fields and farmlands." See Bai, "Multilevel Marketing," supra note 23 at 45 . The relationship between the Republican Party's economic and social policies is explored throughout Thomas Frank, What's the Matter with Kansas? How Conservatives Won the Heart of America (New York: Metropolitan Books, 2004).

27 The accuracy of data about (paper) voter guides is uncertain for instance, the Christian Coalition of America's figure of 70 million guides distributed in 2000 was repeated endlessly without interrogation. The organization's press release containing that figure can be found online: $<$ http://www.cc.org/content.cfm?id=60>. The 2004 guide - in actuality, numerous localized voter guides, plus national guides in English and in Spanish - was accessible on the Christian Coalition's website, online: <http://www.cc.org/voterguides. $\mathrm{cfm}>$.
} 
were re-electing the Christian conservative who appoints federal judges, the Attorney General, other top Justice Department officials, and federal prosecutors. They were, moreover, empowering the Bush Administration to continue to use these appointments to satisfy the most socially conservative wing of the Republican Party. Bush's first-term Attorney General, John Ashcroft, had a lengthy career in Missouri electoral politics (as Governor and U.S. Senator) along with longstanding, very public participation in Christian Right organizations. It was predictable that Bush's judicial appointees would not be "pragmatic," as they were when he was the governor of Texas,${ }^{28}$ but that they would fulfill an ideological mandate to rid the federal bench of "liberal activists." On the Republican agenda for the second term in the White House was bringing several Court of Appeals candidates before the Senate for votes, candidates whose nominations Democrats had blocked and threatened to filibuster because of their very conservative judicial records and/or their extracurricular activities regarding abortion rights, race, and other fraught social issues.

Second, these new voters were solidifying Republican control of the House and the Senate. Perhaps more to the point, they were intensifying as well as transforming the nature of Congressional conservatism. Republicans entering Congress since the watershed 1994 election tend to be more ideological than more senior members. Many moderate Republicans have retired, and some have been defeated in primary elections or lost their seats as the fixed number of House seats have followed the shift of the U.S. population southward and westward. Hence, the great majority of Congressional Republicans vote precisely as key Christian Right groups would have them vote. A major victory for Republicans enabled by the 2004 election was the Senate approval of four conservative Christian nominees to the Court of Appeals (two of them to the influential District of Columbia Circuit Court). A May 2005 deal that secured votes on those judges was negotiated by a bipartisan group of fourteen

28 Lois Romano, "Pragmatism Drove Bush in Texas Judicial Choices" Washington Post (8 July 2005) A04, online: $<$ http://www.washing tonpost.com/wp-dyn/content/article/ 2005/07/07/AR2005070702177.html>. moderate senators. The deal exchanged a promise by the seven Democrats to "filibuster future judicial nominees only under 'extraordinary' circumstances" for the seven Republicans' agreement "to support no changes in Senate rules that would alter the filibuster rule" (in a way that would facilitate ending filibusters).

In the short term, the gloomy reaction on the left - Nan Aron, President of the Alliance for Justice, was " "very disappointed with the decision to move these extremist nominees one step closer to confirmation" "29 - has proven far more warranted than the Christian Right's anger at what Focus on the Family President James Dobson called a "complete bailout and betrayal." "30 To wit: The top item on the Christian Coalition's agenda for Congress in 2005 was a lengthy call to action on "stopping filibusters on President Bush's judicial nominations." ${ }^{31}$ For 2006, "getting votes to confirm President Bush's judicial nominations"dropped to sixth place and is merely a declaration that the organization "will strongly support President Bush's nominee to the Supreme Court, Judge Samuel A. Alito, other future Supreme Court nominees, and nominees to the U.S. Circuit Court of Appeals." ${ }^{32}$

Judicial appointments generate massive media coverage, as well as political capital for members of Congress and interest groups in all ideological camps. Far less attention has been paid to how Congress's legislative agenda may operationalize the general threats against the judiciary that have been issued in such uncensored language and from so many influential conservatives. Vikram Amar contends that, compared with conservatives in the

\footnotetext{
29 Carl Hulse, "Bipartisan Agreement in Senate Averts a Showdown on Judges," New York Times (24 May 2005) A 1. Sixty votes are needed to end a filibuster; fifty-one votes would be needed to change that rule. Thus, in a Senate with fifty-five Republicans and forty-five Democrats (including an independent), the size of the group would prevent both filibusters and rules changes, if the signatories respect the deal.

30 Dan Balz, "For GOP, Deeper Fissures and a Looming Power Struggle" Washington Post (25 May 2005) A11, online: $<$ http://www.washing ton post.com/wp-dyn/content/article/ 2005/05/24/AR2005052401475.html>.

31 Christian Coalition of America, Christian Coalition of America's Agenda for the $109^{\text {th }}$ Congress (2005) [Christian Coalition, Agenda 2005]. (The 2006 agenda replaced the 2005 agenda on the Christian Coalition's website in late 2005.)

32 Christian Coalition of America's Agenda for the 109th Congress, Second Session (2006) [Christian Coalition, Agenda 2006], online: $<$ http://www.cc.org/issues.cfm>.
} 
1960s who advocated the impeachment of Chief Justice Earl Warren (because of Warren Court rulings mandating desegregation, the end of school prayer, and due process protections for the accused, etc.), today's "politicians criticizing the court 'seem to be more reckless. The House and increasingly the Senate don't just vent and say stuff - they also go through the motions and try to pass legislation." " 33 Remaking the federal bench by appointing social conservatives is proving more feasible than impeaching judges for being too "activist" (or for not acting, as in the Terri Schiavo case) or effecting broad-scale jurisdictionstripping. However, the 2004 election emboldened social conservatives in and out of Congress to continue to whittle away at judicial authority. Of the fifteen-point Christian Coalition 2005 agenda for Congress, ${ }^{34}$ seven items were direct attacks on the judiciary or Supreme Court rulings. These included three items urging passage of bills or resolutions narrowing the jurisdiction of federal courts, ${ }^{35}$ one supporting the Marriage Protection Amendment that would excise same-sex marriage from federal court jurisdiction, ${ }^{36}$ and three supporting bills (on abortion and church-state separation) that would surely violate the

33 Quoted in Farhad Manjoo, "Here Comes the Scalias" Slate (11 April 2005), online: <http://www.salon.com/news/feature/ 2005/04/11/judges/index_np.html [Manjoo].

34 Christian Coalition, Agenda 2005, supra note 31.

35 These are the: Constitution Restoration Act of 2005 (H.R. 1070/S. 520), limiting various aspects of federal court jurisdiction and subjecting to impeachment and removal judges who violate the imitations, online: Thomas $<$ http://thomas.loc.gov/cgi-bin/bdquery/z?d109:s.520:>; Pledge Protection Act of 2005 (H.R. 2389/S. 1046), restricting federal court authority over cases about the Pledge of Allegiance, online: Thomas <http://thomas.loc.gov/cgi-bin/bdquery/ z?d109:s.1046:>; and a House Resolution regarding the use of foreign law in court rulings (H. Res. 97), online: Thomas $<$ http://thomas.loc.gov/cgi-bin/bdquery/z?d109:h.res.97:>. For Amar, the jurisdiction-stripping legislation reflects "the absolute lack of sophistication in the way the House of Representatives seems to discuss the courts."' Quoted in Manjoo, supra note 33

36 S. J. Res. 1/H. J. Res. 29, online: Thomas <http://thomas.loc. gov/cgi-bin/bdquery/z?d109:sj1:>. The House has passed the Marriage Protection Amendment (which Senate Democrats filibustered), but not by the two-thirds majority that constitutional amendments require. In addition, the Marriage Protection Act of 2005 (H.R. 1100), online: Thomas $<$ http://thomas.loc.gov/cgi-bin/bdquery/z?d109:h1100:>, would deny federal courts all jurisdiction over constitutional interpretation of the 1996 Defense of Marriage Act, P.L. 104199 (1 U.S.C. § 7 and 28 U.S.C. § 1738C), online: U.S Government Printing Office $<$ http://frwebgate.access.gpo.gov/ cgi-bin/ getdoc.cgi?dbname=104_cong_public_laws\&docid= f:pub1199.104>.
Constitution, at least as interpreted by the thenRehnquist Court.

Finally, the election of 2004 was critical for the courts because it demonstrated, in a more convincing way than ever before, the ability of the Christian Right to transfer electoral strategies from campaigns for office to the realm of direct democracy (i.e., referenda and voter initiatives at the state and local levels). A sophisticated plan to coordinate the placement of constitutional amendments prohibiting same-sex marriage on the ballots in eleven states resulted in eleven state constitutions amended with overwhelming voter support. Added to the five states where voters had previously approved equivalent amendments, the initiative and referendum process represents a significant source of law that, firstly, was written by the Christian Right and, secondly, is substantively immune from state judicial interference. Like other legislation and constitutional amendments supported (mandatory minimum sentences, charter schools) or opposed (gun controls, campaign financing regulations) by the Christian Right, these ballot measures represent a conscious strategy for mobilizing against judicial authority, and elite authority generally. ${ }^{37}$

Political scientists have analyzed the effect of same-sex marriage measures upon the outcome of the Bush-Kerry election in the states where both were on the ballot. Studies conclude that the influence was marginal, although the actual effect on the outcome in states where Bush's margin of victory was very close -i.e., Ohio - is unknown. ${ }^{38}$ Nevertheless, there are reasons beyond the fact of the ballot measures themselves to respect the power of this majoritarian strategy. As it has been transferred from elections for state legislators and mayors to referenda and initiatives, so is it adaptable to other purposes that further the goal of reducing the independence of the American judiciary. Judges are fully 5 percent of the elected

3 Richard J. Ellis, Democratic Delusions: The Initiative Process in America (Lawrence: University Press of Kansas, 2002).

38 Gregory B. Lewis, "Same-Sex Marriage and the 2004 Presidential Election" (2005) 38:2 PS: Political Science and Politics 195; and D. Sunshine Hillygus \& Todd G. Shields, "Moral Issues and Voter Decision Making in the 2004 Presidential Election" (2005) 38:2 PS: Political Science and Politics 201. 
officials in the U.S., and almost all judges must stand for some form of popular election. ${ }^{39}$ Although studies show that judicial elections are heavily dominated by the advertising and campaign contributions of business, labour, and lawyers, state supreme court elections are increasingly affected by the familiar politics of culture and religion. The climate of state judicial elections in 2002 and 2004 bore the imprint of Republican Party of Minnesota v. White. ${ }^{40}$ In that case, the U.S. Supreme Court ruled unconstitutional the Minnesota Supreme Court's "announce clause" barring judicial candidates from publicly taking a position on issues that might come before the court. Now, judicial candidates (most evidently in the South) are volunteering, or being pressured by interest groups to reveal, their positions on reproductive rights, the death penalty, school vouchers, and similar concerns of the Christian Right. ${ }^{41}$ Moreover, the kind of mass politics that direct democracy entails, unlike political contests organized through political parties or within local geographic units, serves as a useful model for large-scale, expensive media campaigns and grassroots organizing around judicial appointments. ${ }^{42}$

\section{CONTROLLING THE SUPREME COURT}

For President Bush, social conservatives and the senators they helped elect, the moment of truth has arrived. - Dr. Richard Land, President, Ethics and Religious Liberty Commission, Southern Baptist Convention ${ }^{43}$

39 Committee for Economic Development, Justice for Hire: Improving Judicial Selection (New York: Committee for Economic Development, 2002) at 1, online: $<$ http://www.ced.org/docs/reports/report_judicial.pdf $>$.

40536 U.S. 765 (2002), online: LII <http://supct.law.cornell.edu/ supct/html/01-521.ZS.html $>$ [White]

${ }^{41}$ See Deborah Goldberg et al., The New Politics of Judicial Elections 2004 (Washington: Justice at Stake Campaign, 2005), online: <http://www.justiceatstake.org/files/ NewPoliticsReport2004.pdf $>$ at 28-33; and Lawrence Baum, "Judicial Elections and Judicial Independence: The Voter's Perspective" (2003) 64 Ohio State Law Journal 13, online: Moritz College of Law <http://moritzlaw.osu.edu/lawjournal/ issues/volume 64/number1/baum.pdf>.

42 See Cooperman, supra note 22.

43 Quoted in Robin Toner, "After a Brief Shock, Advocates on All Sides Quickly Mobilize” New York Times (2 July 2005) A 1.
We were supposed to be meeting on the nomination of Harriet Miers. - Senator Richard Durbin, United States Senate Judiciary Committee ${ }^{44}$

Supreme Court appointments reveal interesting variations within the Christian Right. In some circles, legislatively subjugating the judiciary to the popularly elected branches may be a principled position; often, it is an instrumental goal in a particular case or area of law. Elsewhere within the Christian Right, however, litigation is actually the chosen method for institutionalizing values, as I will show. Despite these differences, the movement is unified in expecting to wield veto power over insufficiently conservative prospective nominees, an expectation that has deepened with Republican control of both the White House and Congress. In the judicial wars, the optimal outcome is ensuring the selection of "judges that never waver" ${ }^{\prime 5}$ in ruling to uphold preferred religious norms and the desired outcomes of interbranch and intergovernmental conflicts. Therefore, it is logical for religious conservative groups to "support efforts that would both radicalize the courts as well as reduce their authority. $" 46$

The retirement in July 2005 of the Supreme Court's most influential member, Justice Sandra O'Connor, and the September death of Chief Justice William Rehnquist unleashed a feeding frenzy by interest groups and members of the Senate. While the efforts to frame the discourse around the nomination and ultimately to determine its outcome took place on the left and right, the first Republican appointment to the Court since 1991 revealed that conservatives who demand impeachment and jurisdiction-stripping will nonetheless devote considerable resources to controlling who sits on the Supreme Court. An imbalance in the mobilization possibilities of the Christian Right compared with its (secular and religious) opponents only amplifies the strength of its dual majoritarian/countermajoritarian strategy with regard to the courts.

44 Quoted in Marcia Davis, "The Unsmoked Signal of Victory on Alito" Washington Post (25 January 2006) C01, online: <www. washington post.com/wp-dyn/content/article/2006/01/24/ AR2006012401846.html>.

45 Manjoo, supra note 33.

46 Ibid. 
The postmodern evangelical equivalent of the phone tree-exhortations to supporters communicated through a web of organizational Internet sites, satellite radio and television stations, and broadcasts to churches - supplemented with direct mailings to homes and media punditry, went into action the moment Justice O'Connor's retirement was announced and with each hospitalization of Chief Justice Rehnquist. ${ }^{47}$ The movement has anticipated a mobilization by the feminist and liberal groups ${ }^{48}$ who defeated Robert Bork's nomination by Ronald Reagan in 1987, who organized against Clarence Thomas in 1991, and who are guaranteed to try to weaken any candidate known to question the legitimacy of Roe $v$. Wade.$^{49}$ In its own rejoinder to the expected liberal response, a Justice Sunday II rally, in Nashville in August 2005, and a Justice Sunday III rally, in Philadelphia in January 2006, were organized to coincide with the Senate confirmation hearings of John Roberts and Samuel Alito. Each successive rally after the original Justice Sunday drew less mainstream media attention; however, it is the simulcasts, rebroadcasts on Christian networks, free audio and video downloads, and DVDs for purchase that highlight the seemingly boundless

47 See Cooperman, supra note 22.

48 Some of the more visible groups and coalitions entering the political fray over the Supreme Court vacancy are: People for the American Way, NARAL-Pro Choice America, NAACP Legal Defense and Educational Fund, Americans United for the Separation of Church and State, Human Rights Campaign, Leadership Conference on Civil Rights, National Women's Law Center, and National Partnership for Women and Families, and National Organization for Women.

49 Supra note 3. Other cases - all decided by 5-4 or 6-3 votes with Justice O'Connor in the majority - that would be sacrosanct for liberal groups include: Atkins v. Virginia, 536 U.S. 394 (2002), online: LII <http://www.law.cornell.edu/ supct/html/00-8452.ZS.html $>$ (forbidding the execution of mentally retarded individuals); Grutter $v$. Bollinger, 539 U.S. 306 (2003), online: LII <http://www.law.cornell.edu/supct/ $\mathrm{html} / 02-241 . \mathrm{ZS} . \mathrm{html}>$ (permitting the promotion of diversity as one consideration in law school admissions); Lawrence $v$. Texas, 539 U.S. 558 (2003), online: LII <http://www.law. cornell.edu/supct/html/02-102.ZS.html $>$ (invalidating, on due process grounds, laws criminalizing homosexual sodomy); Lee v. Weisman, 505 U.S. 577 (1992), online: LII < http://www.law . cornell.edu/supct/html/90-1014.ZS.html> (disallowing a benediction at a public high school graduation ceremony); and Stenberg v. Carhart, 530 U.S. 914 (2000), online: LII <http://www.law.cornell.edu/supct/html/99-830.ZS.html> (striking down Nebraska's criminalization of the methods used most commonly in second- and third-trimester abortions). strategic and resource advantages of the Christian Right in this arena. ${ }^{50}$

It also makes political sense that the Christian Right's invocation of majoritarianism is inconsistent. The majoritarian impulse on the religious right wing of the Republican Party manifests itself both as a deference to elected representatives and a desire to control their participation in the appointment process. It appears as a demand that the voice of tens of millions of evangelical Christians be listened to when justices are chosen, but at the same time as an intolerance of uncertainty-inducing discourse within the nomination process (let alone in the actual act of judging). Hence, Senate Republican and Christian Right leaders rejected Democrats' demands to be consulted during the process of identifying Justice O'Connor's replacement. The idea of a "consensus" nominee to replace Justice O'Connor - i.e., a conservative who could elicit something like consensus within the Senate Judiciary Committee and then attract majorities on a Court that has frequently been divided 5-4 - was categorically rejected by religious conservative groups. Jay Sekulow, who is Chief Counsel of the American Center for Law and Justice (ACLJ) and perhaps the most powerful Christian Right litigator in the United States, efficiently dismissed the possibility of consensus, issuing a press release stating, "'In this case, 'consensus' would mean compromise." 51

50 See David D. Kirkpatrick, "Conservative Gathering is Mostly Quiet on Nominee" New York Times (15 August 2005) A15; and the Justice Sunday website, online: Family Research Council <www.justicesunday.com $>$. Although the liberal People for the American Way, headed by Ralph Neas, may have "generated 600,000 faxes and e-mails to the Senate" against the confirmation of Justice Samuel Alito ("PFAW Hails Strong Tally Against Alito" (31 January 2006) online, $<\mathrm{http}$ ://ww w.pfaw org/p faw/general/d efault. aspx?oid=20393 $>$ ), membership organizations - even wellknown and well-funded ones - cannot maintain a readiness for nationwide mobilization as can groups whose political goals are closed linked to their members' daily activities and lifestyles (including prayer and church-going) and sources of information. These latter groups are exemplified by the Christian Coalition's Judicial Task Force (online: $<$ http://www.cc.org/taskforce.cfm $>$ ) and the Christian Broadcasting Network's Operation Supreme Court Freedom (online: <http://www.cbn.com/special/supremecourt/ prayerpledge.asp $>$ ).

51 Quoted in Carl Hulse \& Richard W. Stevenson, "Senators Advise Bush on Picking a Nominee" New York Time (13 July 2005) A 1 . 
The story of the Bush nominations - of John Roberts (initially nominated to fill O'Connor's seat but soon after to become Chief Justice), of Harriet Miers, and of Samuel Alito - has a clear moral. For the Christian Right, the ideological credentials of appellate court nominees must be guaranteed. The Roberts and Alito nominations were celebrated and defended against attacks from Democrats, whereas the Miers nomination was fatally undermined, because Miers did not have a judicial track record to provide an absolute guarantee of her support for an originalist, socially conservative interpretation of the U.S. Constitution.

Thus, Concerned Women for America (CWA) issued a press release in which its president, Wendy Williams, noted that:

"Harriet Miers has shown respect for Christian values by attending an Evangelical church. But her professional and civic life leaves us questioning whether she chooses to reflect and advance the views of the group she's with at the moment. Though she attends an Evangelical church known for its pro-life position, during the same time period she advanced radical feminists and organizations that promote agendas that undermine respect for life and family...." 52

CW A Chief Counsel Jan LaRue, a star Christian Right litigator who "sp[oke] in favor of Chief Justice John Roberts . . . and f[ound] every opportunity to defend Alito," ${ }^{53}$ elaborated:

"We desire role models who have a strong record of promoting and advancing constitutional principles. Miss Miers' record, as reflected in her speeches, is of promoting a leftist agenda that relies upon the courts to impose their views. ..."54

52 Quoted in "CW A Calls for Miers' Withdrawal" (26 October 2005), online: Concerns Women for America $<$ http://www.cwfa.org/articles/9259/MEDIA/misc/index.htm> [CWA].

53 Marcia Davis, "Expert Witness" Washington Post (9 January 2006) C01, online: <http://www.washingtonpost.com/ wp$\mathrm{dyn} /$ content/article/2006/01/08/AR2006010801256. html>.

54 Quoted in CWA, supra note 52.
This need for guarantees is reflected in the work of the Judicial Confirmation Network, a "team of conservative grass-roots organizers, public relations specialists and legal strategists" who worked for months to ensure the success of any of a list of "18 potential nominees" Bush might pick for the Court - "like-minded jurists who could reorient the federal courts toward a .. . much less expansive view of [the Constitution's] application to individual rights and federal power." ${ }^{55}$ Roberts and Alito were among these candidates ${ }^{56}$ who hold certifiable religious conservative credentials; evidently, Miers was not.

\section{LITIGATION}

The court is their last bastion. That's why the left is so frantic. They can't win democratic elections, they cannot get their aenda through democratic means, so what they are left with is judicial tyranny....James Bopp, Jr., General Counsel, James Madison Center for Free Speech ${ }^{57}$

The Promise Scholarship program practices the plainest form of religious discrimination. - [Solicitor] General Theodore B. Olson on Behalf of the United States as Amicus Curiae Supporting the Respondent ${ }^{58}$

Joshua Davey lost his lawsuit against the State of W ashington, which revoked his college scholarship because of his major in pastoral theology. ${ }^{59}$ Subsequently, he left college for Harvard Law School. ${ }^{60}$ Davey symbolizes an intriguing dimension of the transformation of the New Christian Right into the current Christian Right, the embrace

David D. Kirkpatrick, "In Alito, G.O.P. Reaps Harvest Planted in '82" New York Times (30 January 2006) A 1.

56 Ibid.

57 Quoted in Thomas B. Edsall \& Michael A. Fletcher, "For Liberals, High Stakes at High Court: Another Defeat Could Tarnish Credibility as Advocacy Force" Washington Post (11 July 2005) A 01 , online: <http://www.washingtonpost.com/wp$\mathrm{dyn} /$ content/articles/2005/07/10/AR2005071000923 html $>$.

58 Gary Locke et al. v. Joshua Davey, No. 02-1315, transcript of oral argument (2 December 2003) at 48, online: Supreme Court of the United States <http://www.supremecourtus.gov/ oral_arguments/argument_transcripts/02-1315.pdf $>$.

59 Locke v. Davey, 540 U.S. 712 (2004), online: LII <http://www. law.cornell.edu/supct/html/02-1315.ZS.html $>$ [Davey].

60 See Joshua Davey, "Faith in the Law" Education Next (Summer 2004), online: $<$ http://www.educationnext.org/20043/84.html $>$. 
of litigation as a mechanism for effecting social change. Around the time of Roe, existing evangelical Protestant organizations began creating "litigation spin-offs," "' a trend that accelerated in through the 1980s and especially the 1990s. Christian Right legal organizations participate as amicus curiae, as sponsors of test cases, or as actual litigants in virtually every constitutional case falling within in huge areas of law.

Such a high level of activity, and one that is increasing rapidly, is possible because "evangelical attorneys began to see lawyering as a distinctively religious vocation." ${ }^{.2}$ Relatedly, the growth in Christian Right political advocacy has been accompanied by the construction of a large legal edifice. It consists of public interest law organizations $^{63}$ such as the ACLJ, Alliance Defense Fund, Liberty Counsel, and Home School Legal Defense Association, as well as private law firms and evangelical law schools.

In addition to the overtly Christian legal structure, the influence of the Federalist Society should not be overlooked. This well-known conservative legal think tank, ${ }^{64}$ which was founded in 1982 by lawyers within government, universities, and on the bench, is more obviously libertarian than religious; nevertheless, it has served as a strong institutional and political connection between the established conservative

Hoover \& Den Dulk, supra note 8 at 21.

Ibid. at 25 .

63 Hans J. Hacker, "Defending the Faithful: Conservative Christian Litigation in American Politics," in The Interest Group Connection: Electioneering, Lobbying, and Policymaking in Washington, Paul S. Herrnson, Ronald G. Shaiko \& Clyde Wilcox, eds. (Washington: CQ Press, 2005) 365 at 368-71. For lists of Christian conservative litigation organizations in the U.S. and Canada, see Hoover \& Den Dulk, supra note 8 at 29; also see "Religious Liberty Law Firms," online: David Limbaugh.com < http://www.davidlimbaugh. com/religiousliberty.htm>.

64 The Federalist Society for Law and Public Policy Studies describes itself as:

a group of conservatives and libertarians dedicated to reforming the current legal order. We are committed to the principles that the state exists to preserve freedom, that the separation of governmental powers is central to our Constitution, and that it is emphatically the province and duty of the judiciary to say what the law is, not what it should be.

"Our Background," online: <http://www.fed-soc.org/ ourbackground.htm>. legal community and an evangelical legal community that was new and peripheral until fairly recently. The Federalist Society has a Pro Bono Center whose stated "mission is to match lawyers ... with opportunities for pro bono service in the cause of individual liberty, traditional values, limited government and the rule of law." 65

The Christian Right litigation strategy follows the decades-old American model of liberal constitutional challenges to oppressive state actions like racial discrimination, sex discrimination, church-state intermingling, and censorship. A great deal of the constitutional activity of Christian Right organizations resembles Davey in that it embodies this traditional public interest advocacy model. Some cases involve defending a state-sanctioned status quo - an easy example is siding with a public school district that has a settled practice of reciting the Pledge of Allegiance (containing the phrase "one nation, under God") in its classrooms. ${ }^{66}$

However, the Christian Right has also turned conventional social movement litigation strategy on its head by partnerships with state actors as agents of legal change. Recent examples of this strategy are Congress's passage of the Partial Birth Abortion Act Ban of $2003^{67}$ (after the Supreme Court struck down a similar state statute in $2000^{68}$ ) and, infamously, then-Alabama Supreme Court Chief Justice Roy Moore's installation of a granite Ten Commandments monument in his courthouse. Such actions serve a number of ends, including fuelling populist, evangelical furor against "activist" judges; undermining the legitimacy of even the longest-standing constitutional guarantees of individual liberty, such as the Establishment Clause; paving the way for revising the law in more winnable future cases; and positioning their legal opponents as outside the

\footnotetext{
65 "Mission Statement," online: Federalist Society Pro Bono Center $<$ https://www probonocenter.org/home.aspx $>$.

${ }^{66}$ Elk Grove School District v. Newdow, (2004) 54 U.S. 1 (2004), online: LII <http://www.law.cornell.edu/supct/html/02-1624. ZS.html>. The Supreme Court dismissed the First Amendment challenge to Pledge on procedural grounds.

${ }_{67}$ P.L. 108-105 (18 U.S.C. § 1531), online: U.S. Government Printing Office <http://frwebgate.access.gpo.gov/cgi-bin/ getdoc.cgi?dbname $=108$ _cong_public_laws\&docid=f:pub110 $5.108>$.

${ }_{68}$ Stenberg, supra note 49
} 
American - i.e., Christian (or Judeo-Christian) mainstream.

The many cases in which religious groups are challenging government actions as denials of First Amendment expressive freedoms also demonstrate a radical approach to constitutional litigation. One religion's "free exercise" is another's "establishment of religion" - hence, the lengthy history of challenges by Atheists and Jews to school prayers. Because the reverse is also true, it has been common practice within the Christian Right legal community to challenge denials of religious groups access to public schools, public spaces, and publicly-funded services as Establishment Clause violations and, most recently, as First Amendment free speech violations. The greatest number of victories by the Christian Right have been in situations where the Rehnquist Court interpreted the right to evangelize in airports, engage in after-hours Bible study in public schools, use government-issued tuition vouchers to attend religious schools, or exclude gays and lesbians from group membership as necessary to preventing discrimination. Local land use regulations that do or could possibly affect houses of worship are a growing area of concern for Christian litigators. ${ }^{69}$ This litigation strategy involves the representation of devout Protestants, Catholics, and others ${ }^{70}$ as oppressed minorities deserving the protection of the law, "rather than a majority asserting its will."71

69 See David D. Kirkpatrick, "Ruling on Property Seizure Rallies Christian Groups" New York Times (11 July 2005) A 13; Jay Sekulow, "Protecting Your Property Rights" (1 August 2005), online: ACL J http://www.aclj.org/News/ Read.aspx? ID $=1778>$.

70 See Jim Brown, "Texas High School Agrees to Stop Banning Muslim Students' Prayers" Agape Press (31 January 2006), online: <http://headlines.agapepress.org/archive/1/312006d. asp $>$.

71 Hacker, supra note 55 at 366. The logic and application of this strategy, as well as numerous relevant cases, are examined at length in Steven P. Brown, Trumping Religion: The New Christian Right, the Free Speech Clause, and the Courts (Tuscaloosa: University of Alabama Press, 2002). Also see Kavan Peterson \& Mark K. Matthews, "Evangelical Law Firm at Front of Culture War" (20 June 2005), online: Stateline.org $<$ http://www.stateline.org/live/ViewPage.action? siteNodeId= 136\& language $I d=1 \&$ contentId=38432> [Peterson \& Matthews]

\section{CONCLUSION}

On paper, the judge looked like a model citizen - a 57-year-old Roman Catholic, a registered Republican and a former banking lawyer. But... voters never got a chance to ask him about his judicial philosophy. So they were in for a rude surprise when ... [he] struck down California's voter-approved Defense of Marriage Act. . . . - Candi Cushman, Associate Editor, Citizen ${ }^{72}$

They may be zealots, but they're very smart, well-organized and well-funded. Professor Frank Ravitch, Michigan State University College of $\mathrm{Law}^{73}$

Ultimately, the legal element of Christian Right political advocacy can be characterized as radical because of its combination of powerful majoritarian and countermajoritarian strategies for influencing who interprets the Constitution and how they interpret it. It is true that the mix of electoral, grassroots, and legal tactics - including, it must be noted, the role of religion in advancing social change - resembles the strategies used successfully by liberals in the 1950s and 1960s. However, there are several significant differences between then and now, and between the political power of the predominant social movements of each era. As I have shown, religious conservatives insist on receiving guarantees of the broad ideologies and interpretive stances of appellate judges. Where Supreme Court appointments are at stake, a Republican President and Republican Congressional leaders will take instruction from Christian Right leaders and followers. Government officials launch attacks on judges and courts that question, often explicitly, judicial independence and the rule of law. Finally, the Christian Right has at its disposal a sophisticated communications network that can reach tens of millions of followers both during and between elections.

\footnotetext{
72 Candi Cushman, "Bad Behavior" Citizen (June 2005), online: Family.org <http://family.org/cforum/fosi/ government/courts/state/a0036435.cfm $>$. The judge in question is San Francisco County Superior Court Judge Richard Kramer. 73 Quoted in Peterson \& Matthews, supra note 70.
} 
Liberals are certainly not without legal wherewithal: The ACLU, for instance, "handles nearly 6,000 civil rights-related law suits per year" and "is reported to have a $\$ 100$ annual budget." 74 But the ACLU is not remaking the federal and state courts in its image; it is not shifting the interpretation of the First Amendment to redefine permissible public religious expression, nor of a protected minority. Roe v. Wade, decided a generation ago, was the zenith of the Court's protection of reproductive rights. The perceived assault on traditional marriage against which religious conservatives vote and litigate is based on actual events, but movement towards same-sex marriage rights is tiny and tenuous. On the whole, then, at this historical moment in the United States, the Christian Right approach to judges, courts, and the law can only be seen as a success. ${ }^{75}$

\section{Judith A. Garber}

Department of Political Science

University of Alberta

Executive Director, Centre for

Constitutional Studies

jgarber@law.ualberta.ca

Ibid.

75 In May 1995, National Public Radio aired a five-part series, Christianity and the Public Square," by reporter Margaret Bradley Haggerty, that addressed many of the issues discussed in this article. The broadcasts are available online: $<$ http://www npr.org/templates/story/story.php? storyId=4631923>. 